\title{
Correlation Between Level of Depression and Risk of Suicide in Elderly at Purwodadi, Grobogan
}

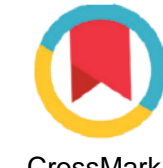

\author{
Rilla Fiftina Hadi ${ }^{1}$, Titis Hadiati ${ }^{1}$, Natalia Dewi Wardani ${ }^{1 \star}$
}

${ }^{1}$ Department of Psychiatry, Faculty of Medicine, Diponegoro University, Indonesia

Keywords:
Elderly
Level Depression
Suicide risk
GDS
CSSRS

*) Correspondence to: anatdew@gmail.com

Article history:

Received 30-11-2020

Accepted $04-12-2020$

Availableonline10-12-2020

\begin{abstract}
Background: According to WHO, the elderly people have physical and mental challenges, including depression. The incidence of depression lead to suicide on elderly is about $12.7 \%$. In Grobogan Regency, Purwodadi, Central Java, there has been an increase of depression in the last 5 years. Purwodadi Sub district depends on the number of orders with the highest number of traffic cases and the elderly.

Objective: To determine the correlation between depression level and the risk of suicide.

Methods: This research is a quantitative study with cross sectional design in which all respondents were observed and variables were measured at one time. Samples were taken from elderly outpatient of primary health care and Posyandu lansia at Purwodadi, who met the inclusion and exclusion criterias. Research samples were selected based on nonprobability sampling method through purposive sampling. This research used the Indonesian version of the GDS (Geriatric Depression Scale) and CSSRS (Columbia Suicide Severity Rating Scale) questionnaire.

Results: The prevalence of elderly depression is $63.3 \%$, and a significant correlation was found between severe depression and low risk of suicide $(\mathrm{p}<0.05)$

Conclusion: significant correlation was found between severe depression and low risk of suicide
\end{abstract}

DIMJ, 2020, 1(2), 56-60 DOI: https:// doi.org/10.14710/dimj.v1i2.9585

\section{Introduction}

Getting older is an inevitable phase of life, especially when someone enters the elderly phase. Elderly phase is a process generally involves decreasing cognitive and physical abilities. This process is attributed with the decrease of several physiological functions due to degenerative processes (aging), including biological, physical, psychological and social aspects, leading to many noncommunicable diseases. ${ }^{1}$

According to WHO, the elderly may face physical and mental health challenges that must be addressed immediately, including depression. The cause of depression is commonly due to an increased risk of getting various physical illnesses ${ }^{1,2,3}$. Depression in the elderly is often regarded as a normal part of aging thus it is often ignored. The elderly with depression are about 5.7$7 \%$ of world population ${ }^{4}$. Previous research reported that depressed elderly in United States and
China with suicidal ideation were about $48.7 \%$ / 100,000 population and $140 / 100,000$ population, respectively, at the age of more than 60 years. In United States, $12.7 \%$ of depressed elderly commited suicide. ${ }^{2}$

Grobogan is one of the districts in Central Java which is near to the capital of province, Semarang. Total population of Grobogan in 2016 was about $1,343,960$ and spread in 19 sub-districts, which reported an increased number of suicide in the past 5 years. As one of sub-district in Grobogan, Purwodadi reported 13.903 people aged more than 60 in 2016, and recorded third highest suicide rate in the elderly compared to the other subdistricts. ${ }^{5}$ To date, data on depressed elderly with a risk of suicide in Central Java has not been established, including in Purwodadi District, Grobogan Regency. 
Furthermore, there was previous researches did not evaluate the relationship between the elderly suffering from depression with the risk of suicide in Purwodadi, Grobogan. Whereas, there is an increase in the number of suicide, thus we conducted a collaboration study with other researchers as an answer to this problem.

\section{Methods}

\section{Design, Time and Place}

This study is a quantitative research with cross sectional design. The subjects were elderly who came to outpatient polyclinics and Posyandu Lansia at Purwodadi Primary Health Care. The research was conducted in January to February 2020 in Purwodadi, Grobogan.

\section{Subject}

The subject of this study was the elderly who came to outpatient clinic and posyandu lansia in Purwodadi Primary Health Care. The inclusion criteria were as follows: male or female aged 60 years and older, able to read and write, with compos mentis awareness were willing to join the study by signing informed consent. The minimum sample size needed in this study was 60 people. Sampling was done by non-probability sampling through purposive sampling. ${ }^{6}$

Tools

Data collected in this study were primary data obtained from 2 questionnaires. The first questionnaire was based on the Geriatric Depression Scale-15 (GDS-15), which will detect level of depression in the elderly. ${ }^{7}$ The second questionnaire was the Columbia Suicide Severity Rating Scale (CSSRS), that will detect the risk of suicide, categorized into three level of risk ${ }^{8}$ and no risk if the answer is "No" to all questions.

\section{Processing and data analysis}

Data processing was carried out using SPSS software. Analysis test was done using the chi-square test.

\section{Result}

\section{Basic characteristics of respondents}

In this study the youngest and oldest respondents were 60 and 87 years old, respectively. The proportion of males to female respondents was relatively balanced at $43.3 \%$ to $56.7 \%$, respectively. Most of the subjects $(81.7 \%)$ had low education, ranging from uneducated to elementary school graduate. Employment status was also balanced, in which employed and unemployed were both 50\%, with most of subjects (88.3\%) had an income level of less than Rp. 2,000,000. Married subjects were about $66.7 \%$, while $33.3 \%$ were divorced. Most subjects had chronic pain (65\%) for less than 1 year (74.3\%).

Tabel 1. Distribution of Demographic Characteristics

\begin{tabular}{|c|c|c|}
\hline Variable & $\mathrm{n}$ & $\%$ \\
\hline \multicolumn{3}{|l|}{ Age } \\
\hline $66,58 \pm 6,53$ & & \\
\hline \multicolumn{3}{|l|}{ Median (Range) 64,5 (60-87) } \\
\hline $60-74$ year & 51 & 85 \\
\hline 75 - 90 year & 9 & 15 \\
\hline Sex & 26 & 43,3 \\
\hline Male & 20 & 45,3 \\
\hline Female & 34 & 56,7 \\
\hline \multicolumn{3}{|l|}{ Religion } \\
\hline Islam & 59 & 98,3 \\
\hline Budha & 1 & 1,7 \\
\hline \multicolumn{3}{|l|}{ Marriage } \\
\hline Married & 40 & 66,7 \\
\hline Death divorce & 20 & 33,3 \\
\hline \multicolumn{3}{|l|}{ Education } \\
\hline Elementary School & 46 & 76,7 \\
\hline Junior High School & 9 & 15,0 \\
\hline Senior High School & 2 & 3,3 \\
\hline $\begin{array}{l}\text { Occupation } \\
\text { Unemployed }\end{array}$ & 29 & 48,3 \\
\hline Labor/farmer & 24 & 40,0 \\
\hline Entrepreneur & 6 & 10,0 \\
\hline Retired & 1 & 1,7 \\
\hline \multicolumn{3}{|l|}{ Income } \\
\hline$<2$ million & 53 & 88,3 \\
\hline $2-3$ million & 5 & 8,3 \\
\hline $3-5$ million & 2 & 3,3 \\
\hline \multicolumn{3}{|l|}{ Chronic Illness } \\
\hline Yes & 39 & 65,0 \\
\hline No & 21 & 35,0 \\
\hline \multicolumn{3}{|l|}{ Onset Chronic Illness } \\
\hline$>5$ year & 10 & 25,6 \\
\hline $1-5$ year & 19 & 48,7 \\
\hline$<1$ year & 10 & 25,6 \\
\hline
\end{tabular}

\section{Depression Levels Based on Research Subject} Characteristics

This study reported that men $(69.2 \%)$ suffer depression more than women $(58.8 \%)$ at age of 75 $90(77.8 \%)$ more than 60-74 (60.8\%). Divorced subjects $(70 \%)$ suffer more depression than married subjects $(60 \%)$. Uneducated subjects $(66.7 \%)$ and elementary school graduated showed a depression rate of $65.2 \%$, while junior high school graduated subjects was $66.6 \%$ and high school graduates reported no depression. Subjects who was unemployed had more depression $(68.9 \%)$ than farmers $(62.5 \%)$, and entrepreneurs $(50.1 \%)$, while those who worked as civil servant did not suffer from depression. Subjects with income rate less than Rp. 2 million (67.9\%) suffered from depression, while 
those with income range from Rp. 2 million-Rp. 3 million (40\%) and Rp. 3 million to Rp 5 million showed no depression. Subjects with and without chronic disease showed depression rate of $71.8 \%$ and
$47.7 \%$, respectively. Subjects with chronic illness more than 5 years, $1-5$ years, and less than 1 year showed depression rate of $70 \%, 68.4 \%$, and $80 \%$, respectively.

Table 2. Depression level based on subject characteristic based on chi square test

\begin{tabular}{|c|c|c|c|c|c|c|c|c|c|}
\hline \multirow{3}{*}{ Variable } & \multicolumn{8}{|c|}{ Level of Depression } & \multirow{3}{*}{$\mathbf{p}$} \\
\hline & \multicolumn{2}{|c|}{ Severe } & \multicolumn{2}{|c|}{ Moderate } & \multicolumn{2}{|c|}{ Mild } & \multicolumn{2}{|c|}{ Not Depressed } & \\
\hline & $\mathbf{n}$ & $\%$ & $\mathrm{n}$ & $\%$ & $\mathrm{n}$ & $\%$ & $\mathrm{n}$ & $\%$ & \\
\hline \multicolumn{10}{|l|}{ Sex } \\
\hline Male & 5 & 19,2 & 3 & 11,5 & 10 & 38,5 & 8 & 30,8 & 0,424 \\
\hline Female & 2 & 5,9 & 5 & 14,7 & 13 & 38,2 & 14 & 41,2 & \\
\hline \multicolumn{10}{|l|}{ Age } \\
\hline $60-74$ & 6 & 11,8 & 7 & 13,7 & 18 & 35,3 & 20 & 39,2 & 0,446 \\
\hline $75-90$ & 1 & 11,1 & 1 & 11,1 & 5 & 55,6 & 2 & 22,2 & \\
\hline \multicolumn{10}{|l|}{ Religion } \\
\hline Islam & 7 & 11,9 & 8 & 13,6 & 23 & 39 & 21 & 35,6 & 0,624 \\
\hline Budha & 0 & 0 & 0 & 0 & 0 & 0 & 1 & 100 & \\
\hline \multicolumn{10}{|l|}{ Marriage } \\
\hline Married & 4 & 10 & 4 & 10 & 16 & 40 & 16 & 40 & 0,629 \\
\hline Death Divorced & 3 & 15 & 4 & 20 & 7 & 35 & 6 & 30 & \\
\hline \multicolumn{10}{|l|}{ Education } \\
\hline Uneducated & 0 & 0 & 0 & 0 & 2 & 66,7 & 1 & 33,3 & 0,626 \\
\hline Elementary School & 7 & 15,2 & 6 & 13 & 17 & 37 & 16 & 34,8 & \\
\hline Junior High & 0 & 0 & 2 & 22,2 & 4 & 44,4 & 3 & 33,3 & \\
\hline Senior High & 0 & 0 & 0 & 0 & 0 & 0 & 2 & 100 & \\
\hline \multicolumn{10}{|l|}{ Occupation } \\
\hline Unemployed & 4 & 13,8 & 3 & 10,3 & 13 & 44,8 & 9 & 31 & 0,895 \\
\hline Labor/farme & 2 & 8,3 & 4 & 16,7 & 9 & 37,5 & 9 & 37,5 & \\
\hline Enterpreneur & 1 & 16,7 & 1 & 16,7 & 1 & 16,7 & 3 & 50 & \\
\hline Retired & 0 & 0 & 0 & 0 & 0 & 0 & 1 & 100 & \\
\hline \multicolumn{10}{|l|}{ Income } \\
\hline$<2$ million & 6 & 11,3 & 8 & 15,1 & 22 & 41,5 & 17 & 32,1 & 0,404 \\
\hline 2-3 million & 1 & 20 & 0 & 0 & 1 & 20 & 3 & 60 & \\
\hline 3-5 million & 0 & 0 & 0 & 0 & 0 & 0 & 2 & 100 & \\
\hline \multicolumn{10}{|l|}{ Chronic Illness } \\
\hline Yes & 6 & 15,4 & 7 & 17,9 & 15 & 38,5 & 11 & 28,2 & 0,153 \\
\hline No & 1 & 4,8 & 1 & 4,8 & 8 & 38,1 & 11 & 52,4 & \\
\hline \multicolumn{10}{|l|}{ Onset Chronic Illness } \\
\hline$>5$ year & 3 & 30 & 1 & 10 & 3 & 30 & 3 & 30 & 0,542 \\
\hline $1-5$ year & 3 & 15,8 & 3 & 15,8 & 7 & 36,8 & 6 & 31,6 & \\
\hline$<1$ year & 0 & 0 & 3 & 30 & 5 & 50 & 2 & 20 & \\
\hline
\end{tabular}

\section{Level of Depression}

Depression levels were measured using the GDS score. Overall, there were 22 people without depression (36.7\%), 23 people with mild depression (38.3\%), 8 people with moderate depression $(13.3 \%)$ and 7 people with severe depression $(11.7 \%)$. This shows that the elderly who suffer from depression as much as $63.3 \%$. From the data above, it can be seen that most of the subjects had mild depression. This value is greater than moderate depression and major depression.
Table 3. Distribution of study subjects based on the level of depression

\begin{tabular}{lcc}
\hline Level of Depression & $(\mathrm{n}=60)$ & $(\%)$ \\
\hline Severe & 7 & 11,7 \\
Moderate & 8 & 13,3 \\
Mild & 23 & 38,3 \\
Not Depressed & 22 & 36,7 \\
\hline Total & 60 & 100,0 \\
\hline
\end{tabular}

\section{Correlation Between Depression Levels in the Elderly and the Risk of Suicide}

The result of bivariate analysis using Chi Square test showed a significant relationship between major depression and the risk of suicide $(\mathrm{p}=0.025)$. 
Tabel 4. Correlation between depression level and suicide risk

\begin{tabular}{lccccc}
\hline \multirow{2}{*}{$\begin{array}{l}\text { Level of } \\
\text { Depression }\end{array}$} & \multicolumn{4}{c}{ Suicide Risk } & \multirow{2}{*}{$\mathrm{p}$} \\
\cline { 2 - 4 } & \multicolumn{2}{c}{ Low Risk } & \multicolumn{2}{c}{ No Risk } & \\
\cline { 2 - 5 } & $\mathrm{n}$ & $\%$ & $\mathrm{n}$ & $\%$ & \\
\hline Severe & 4 & 57,1 & 3 & 42,9 & $0,025^{*}$ \\
Moderate & 2 & 25 & 6 & 75 & \\
Mild & 6 & 26,1 & 17 & 73,9 & \\
Not & 1 & 4,5 & 21 & 95,5 & \\
Depressed & & & & \\
\hline
\end{tabular}

Note: * Significant $(\mathrm{p}<0,05), r=0,236$

\section{Discussion}

It is noteworthy to say that the result of this study is interesting to be discussed further. The prevalence of depression in the elderly was found to be $63.3 \%$. Most respondents who suffer from depression are male aged 75-90 years. As we get older the risk of depression is also increased but not to the extent of major depression. One of the factor protecting the elderly from moderate or severe depression is possibly because the elderly tend to live in a harmony with nature, increasing in terms of religious, social and cultural observance. The desire to get closer to God in the elderly is relatively effective in preventing worse depression and avoiding suicidal thoughts; it is supported by the fact that Purwodadi sub-district is one of 3 santri cities in Grobogan Regency., ${ }^{9,10}$

The elderly with no spouse showed high potential for depression. It can be concluded that talking partners and friends in life can be a protective factor. Subjects with low education showed a greater incidence of depression than those of higher education. The ability to adapt to overcome problems and more sophisticated way of thinking also contribute to prevent depression. Most unemployed elderlies (69\%) experienced depression. This figure is smaller compared to other studies. Being productive and not a burden to relatives allegedly can prevent depression. Having physical ailments and illnesses for less than 1 year can contribute for depression as much as $80 \%$. In addition to feel as a burden to the relatives, suffering illnesses for more than 1 year indicating that the elderlies were able to adapt to their limitations. ${ }^{9}$

In terms of the risk of suicide, major depression has a significant relationship to low suicide risk. This result possibly caused by the fact that most subjects are Muslim and lived in Purwodadi, which is one of the santri cities. It is in accordance with another protective factor, i.e., religion, as a system of beliefs that may discourage suicide. Closeness to God can be a deterrent to suicidal thoughts and behavior. ${ }^{10}$

\section{Conclusion}

This study found that the prevalence of depression in the elderly is about 63.3\%. Depression was observed more on male elderly, aged more than 75 years, divorced, low education, unemployed, income level less than Rp. 2 million, with comorbid chronic pain, and duration of illness less than 1 year. Two levels of risk, namely no risk and low risk, were found on subjects. Most subjects showed no risk of suicide and did not suffer from depression, while low risk of suicide was mostly found in subjects with severe depression. There is a significant relationship between major depression with the risk of suicide.

This study suggests the necessity to improve health services, especially depression and suicide risk screenings for the elderly in health services, especially in Primary Health Care. Education to family on high risk factors for depression, especially understanding depression, complaints of depression in the elderly, the course of depression, and treatment of depression is also important to reduce suicide rates in the elderly.

\section{Ethical Approval}

Ethical clearance has been approval by Komisi Etik Penelitian Health Research Ethics Committee Faculty of Medicine, Diponegoro University. The number of ethical clearance is 01/EC/KEPK/FKUNDIP/I/2020.

\section{Conflict of Interest}

The authors declare no conflict of interest

\section{Funding}

No specific funding was provided for this article

\section{Author Contributions}

The contributions to this research are as follows: "conceptualization, Titis and Rilla; methodology, Natalia; software, Rilla; validation, Titis, Natalia, and Rilla; formal analysis, Natalia; investigation, Titis; resources, Rilla; data curation, Rilla; writingoriginal draft preparation, Rilla; writing - review and editing, Rilla; visualization, Rilla; supervision, Titis dan Natalia; project administration, Titis; funding acquisition, Natalia.

\section{Acknowledgements}

This work was supported by Department of Psychiatry, Faculty of Medicine, Diponegoro University. We thank to Puskesmas, Posyandu at 
Puskesmas Purwodadi and all participants and their families.

\section{References}

1. Kementerian Kesehatan RI. PMK No. 25 ttg Rencana Aksi Nasional Kesehatan Lanjut Usia Tahun 2016-2019. Jakarta. 2016.10-6.

2. Conejero I, Olié E, Courtet P. \& Calati R. Suicide in Older Adults : The Role of Emotions and Cognition.NCBI.2015.13.691-99. doi:10.11007/s11920-014-0495-3.

3. Maramis M. Depresi Pada Lanjut Usia. Widya Medika Surabaya. 2014. 2(1): 27-28. http://journal.wima.ac.id/index.php/JWM/articl e/download/1650/1511.

4. World Health Organization. Mental health of older adults. Available at: who.org. 2017.

5. Badan Pusat Statistik. Presentase Jumlah Penduduk Menurut Umur. 2016. Available from:https://www.bps.go.id/statictable/2014/09 /05/1533/persentase penduduk menurut umur dan kecamatan tahun. html. Accesed October
16, 2019

6. Dahlan M. Besar Sampel dan Cara Pengambilan Sampel dalam Penelitian Kedokteran dan Kesehatan. Jakarta. Salemba Medika. 2013.

7. Indawati, R., Basuki N, Qomaruddin BM, Mahajudin SM, Asiyah NS. Screening Performance of the Geriatric Depression Scale (GDS-15) for Elderly in the Community, Indonesia. Int. J. Res. Advent Technol. 2016.4 (12) :11-14. Available online at www.ijrat.org.

8. Pratiwi J. Suicide Ideation Pada Remaja Di Kota Semarang.www.journal.unnes.ac.id.2014.3(1):2 4

34. http://journal.unnes.ac.id/sju/index.php/dcp.

9. Brooks S, Burruss S. Suicide in the Elderly A Multidisciplinary Approach to Prevention. Clinical Geriatry Med. 35. 2019. 133-145 https://doi.org/10.1016/j.cger.2018.08.012.

10. Chen Y, Tsai Y, Lee S, Lee H. Protective factors against suicide among young-old Chinese outpatients. BMC Public Health. 2014. 14:372.http://www.biomedcentral.com/14712458/14/372. 